\title{
The Reserve Bank of Australia's pandemic response and the New Keynesian trap
}

\author{
Stephen Kirchner ${ }^{1}$
}

\section{Abstract}

The Reserve Bank of Australia (RBA) has been overly wedded to a New Keynesian conception of the monetary policy transmission mechanism, in which the official cash rate is seen as the main instrument for policy implementation and the main measure of the stance of monetary policy. The 'effective lower bound' on the official cash rate became an artificial, selfimposed constraint on the RBA's initial response to the Covid-19 pandemic. By contrast, a monetarist conception of the monetary transmission mechanism would have encouraged more rapid adoption of alternative operating instruments.

Reserve Bank of Australia Governor Phillip Lowe characterised the Covid-19 pandemic as the worst shock to the Australian economy in 100 years. Yet the bank's initial response to the pandemic in March 2020 was limited, seeking to exhaust the possibilities of its pre-pandemic operating instruments. While Australia's fiscal policy response was in line with that of other advanced economies, its monetary response, measured by the expansion in its balance sheet, lagged that of its G10 peers. Only in November 2020 did the RBA resort to alternative operating instruments to play catch-up with other central banks. In the intervening period, Australia's fiscal and monetary policy mix saw the Australian dollar outperform its G10 peers-a classic case of open-economy crowding-out.

1 United States Studies Centre, University of Sydney; stephen.kirchner@sydney.edu.au. The author’s newsletter can be found at stephenkirchner.substack.com. 
This article will argue that the RBA was overly wedded to a New Keynesian conception of the monetary policy transmission mechanism, in which the official cash rate is seen as the main instrument for policy implementation and the main measure of the stance of monetary policy. The 'effective lower bound' on the official cash rate became an artificial, self-imposed constraint on the RBA's initial pandemic response. In contrast, a monetarist conception of the monetary transmission mechanism would have encouraged more rapid adoption of alternative operating instruments.

Before the pandemic, Governor Lowe signalled his reluctance to embrace alternative operating instruments, questioned their effectiveness and hinted vaguely at unwelcome costs associated with easier monetary policy (Lowe, 2019). Both before and during the pandemic, Lowe called on federal and state governments to do more with fiscal and structural policy, implicitly conceding that macroeconomic policy settings were inadequate, even though the RBA itself had scope to do more. The RBA eventually embraced quantitative easing (QE), from November 2020, with an aggressive program of longer-duration outright Commonwealth and semigovernment bond purchases. The RBA conceded that its failure to expand its balance sheet as had other central banks had put upward pressure on the exchange rate.

While the RBA has committed to maintaining what it sees as accommodative policy settings until its inflation and full employment objectives are met, this commitment to the duration of accommodation has been allowed to substitute for the more aggressive policy action that would see the RBA meet its objectives more quickly. Extended periods of low interest rates are indicative not of 'easy' monetary policy, but of a monetary policy that is too tight.

This article concludes with suggestions for improving the performance of Australian monetary policy—in particular, a nominal income-level target informed by a monetarist conception of monetary policy transmission.

\section{Pre-pandemic monetary policy and the 'Lowe gap'}

The RBA has failed consistently to meet its inflation target since the end of 2014. While small inflation target misses in any given quarter are unlikely to be consequential, a persistent multiyear miss gives rise to long-run drift in the price level relative to expectations conditioned on the inflation target. The long-run drift in the price level means the expectations for nominal income that inform long-term nominal contracting have been disappointed. 
The 'Lowe gap' is defined as the excess of a 'trimmed mean' measure of the (log) $\mathrm{CPI}$ over a counterfactual inflation target-consistent path for the period since Lowe became RBA Governor in the third quarter of $2016 .{ }^{2}$ Note that because the RBA was undershooting the inflation target before then, this starting point understates the long-run drift in the price level due to the RBA's inflation target misses.

In the first quarter of 2020, the Lowe gap was -3.9 per cent. In the period since, it has widened to -4.4 per cent, as of the second quarter 2021 . Note that even if the RBA were to return inflation to the target range-something it has pencilled in from the middle of 2023 - the price level will be permanently lower relative to a target-consistent counterfactual growth path. This is the sort of permanent nominal shock that flexible price-level targeting-what the US Federal Reserve calls average inflation targeting - seeks to offset. Targeting a forecast for the level of nominal GDP aims to avoid the long-run drift in nominal outcomes that can occur under the RBA's let-bygones-be-bygones approach to inflation targeting (Kirchner, 2021).

At its February 2020 meeting, just before the onset of the pandemic, the RBA Board decided to leave its official cash rate target unchanged at 0.75 per cent. The headline consumer price index inflation rate for the previous quarter was running at 1.8 per cent. Inflation had been below the target on most measures since the end of 2014 and was expected to remain so over the bank's two-year forecast period. The unemployment rate for December 2019 was 5.1 per cent-virtually unchanged from a year earlier and above the RBA's estimate of the full employment rate of around 4.5 per cent, having never recovered the lows around 4 per cent seen before the 2008 Global Financial Crisis. The RBA Governor told a parliamentary committee a few days later 'there is a risk that further cuts in interest rates could encourage further borrowing. If people borrow more, then perhaps down the track we have problems' (Lowe, 2020a). Lowe's remarks were typical of numerous statements he made since becoming governor that explicitly traded-off the inflation target and full employment objectives against apprehended financial stability risks (Kirchner, 2018).

\section{Monetary policy during the pandemic}

Within weeks of Governor Lowe's testimony, the Australian and world economies suffered a massive shock as the Covid-19 virus became a global pandemic. The RBA's initial response to the pandemic shock was to lower the official cash rate target by 50 basis points in two moves over the course of March 2020, to 0.25 per

2 See Stephen Kirchner (2021). The Widening Lowe Gap. Institutional Economics, 29 July, stephenkirchner. substack.com/p/the-widening-lowe-gap. 
cent - a rate it had previously argued was an effective lower bound (ELB) given the floor of the usual 25-basis-point corridor around the cash rate target would then be 0 per cent (Lowe, 2020b).

The reduction in the target cash rate was accompanied by a commitment (or forward guidance) not to raise the target 'until progress is being made' to restoring full employment and returning inflation to the target. This was little different to the RBA's previous, pre-pandemic guidance, which was already committed to keeping interest rates 'low' for an extended period based on the same criteria. The 'progress being made' commitment was ambiguous, although stronger than the guidance usually offered by the bank. Any prospective improvement in the economy could be interpreted as 'progress' and see markets pricing in a premature increase in the cash rate, even in the absence of a change in the target rate.

The RBA reinforced this commitment by undertaking to intervene in the bond market to keep the three-year bond yield close to 0.25 per cent, compared with a then prevailing market yield of around 0.50 per cent-an approach sometimes dubbed 'yield curve control' (YCC) or 'yield curve targeting' (YCT). By offering to buy government bonds at an implied target yield, the target effectively became the market yield, although Governor Lowe indicated the intervention was not a strong peg like that normally applied to the cash rate, allowing some flexibility.

The aim of the yield curve target was to hold down the front and middle parts of the yield curve that serve as the risk-free benchmark for most retail and wholesale lending rates in Australia. It was complemented by a Term Funding Facility (TFF) designed to ensure banks could borrow at this rate. If the RBA's commitment to hold the cash rate at 0.25 per cent 'for some years' were fully credible then intervention on the three-year bond would be unnecessary, and that mostly proved to be the case. After some initial outright bond purchases, the RBA did not intervene in the secondary bond market between early May and early August 2020, when threeyear yields rose modestly, triggering renewed intervention. Governor Lowe explicitly nominated three years as the likely time frame for keeping the cash rate at 0.25 per cent, reinforcing the loose peg on the three-year bond. Longer-term interest rates were still largely market-determined, although the RBA intervened heavily in the bond market in March 2020 to maintain liquidity amid a global bond market sell-off as investors sought to raise cash.

The RBA's preference for YCC reflected its aversion to both negative interest rates and major balance sheet expansion via large-scale asset purchases-the two main policy instruments that could have been employed in addition to forward guidance and instead of a yield target. Governor Lowe all but ruled out both options in a speech in November 2019 (Lowe, 2019), saying both options were very unlikely, raising the reputational cost to reversing that position during the pandemic. The RBA views monetary policy transmission largely in terms of the risk-free interest rate structure 
(and, by extension, the exchange rate) rather than in terms of quantities such as real money balances, although its own research shows a correlation between broad money aggregates and nominal GDP (Doherty et al., 2018). Having lowered the cash rate to what it viewed as the ELB and committed to keeping short-term rates at this level for an extended period, the RBA considered it had done enough to respond to the pandemic shock, but this dramatically underestimated the possibilities for monetary policy, particularly in lowering the exchange rate, which immediately appreciated under the March 2020 policy framework.

This left Australia's macroeconomic response to the pandemic heavily skewed towards fiscal policy—a shift the RBA actively encouraged by calling on the Commonwealth and states to increase spending over and above an already large fiscal policy response. This was a suboptimal macroeconomic policy mix for a small, open economy, with Australia's relatively high long-term interest rates attracting foreign capital inflows, appreciating the exchange rate and crowding out net exports. While the yield curve target held down the short end of the yield curve, Australia still enjoyed a long-term yield premium of around 100 basis points over other AAA-rated sovereign nations and economies on the euro area periphery. Both short and long yields have a role in exchange rate determination.

As the pandemic downturn deepened and the exchange rate appreciated, the RBA Board publicly canvassed its options for doing more. It adapted its forward guidance in October 2020 to say that the official cash rate would only be increased if actual inflation were in the target range (rather than just being forecast in the range) and the unemployment rate were consistent with inflation remaining within that range, which the RBA had previously identified as a rate of around 4.5 per cent. It also argued that its financial stability concerns had shifted to mitigating the effects on the financial system of the downturn in the economy, in contrast to its pre-pandemic preoccupation with risks arising from increased household leverage. Oddly, this significant change in the RBA's forward guidance was made at the end of a speech to an investment bank conference rather than as a statement after a board meeting (Lowe, 2020c).

At its November 2020 meeting, the RBA Board announced a further lowering in the official cash rate target, to 0.10 per cent. The TFF rate and three-year bond yield target were also lowered to 0.10 per cent, while the rate on exchange settlement account (ESA) balances was lowered to 0 per cent, presumably with a view to encouraging financial institutions to increase lending or purchase other assets with their ESA balances. At the same time, the RBA announced a $\$ 100$ billion bondbuying program over the next six months. The program recognised that expansion of the RBA's balance sheet had lagged that of other central banks and this had put upward pressure on the exchange rate. The RBA argued that the reason it had not acted earlier was that pandemic lockdowns would have reduced the traction 
of monetary policy over the economy, although this concern had not previously been mentioned by the RBA as a constraint on the effectiveness of monetary policy, making it sound like an expost rationalisation of previous policy inaction.

Together with the October change in forward guidance, the RBA's actions in November 2020 were welcome recognition that its earlier pandemic response had been inadequate. It also demonstrated that 0.25 per cent was not an ELB for the official cash rate or the contribution monetary policy could make to stabilising the economy. The RBA could have employed negative interest rates as either its official cash rate target or for the rate paid on ESA balances.

At its February 2021 meeting, the RBA Board committed to an additional $\$ 100$ billion in bond purchases once the then extant bond-buying program was completed in April, of around \$5 billion per week. In evidence before the House of Representatives Standing Committee on Economics that month, Governor Lowe gave little indication that the RBA had given serious consideration to the size of the bond purchase program needed to realise its inflation target or contemplated the implications of the US Federal Reserve's shift to a flexible price-level target because of the Fed's long-term strategy review.

At the bank's July 2021 meeting, this rate of bond purchases was tapered to $\$ 4$ billion a week from September, but with no commitment to the overall size of the program and with a further review scheduled for November 2021. At the same time, the board decided not to roll forward its yield curve target from the April to the November 2024 bond, allowing the duration of the yield curve target to fade in line with the RBA's expectation of an eventual increase in the official cash rate sometime in 2024. The TFF also expired at the end of June 2021.

Governor Lowe's press conference following the RBA's recalibration of its policy settings in July 2021 was remarkable for the extent to which he took ownership of inflation and nominal wage outcomes. The RBA had previously noted weakness in the nominal side of the economy, but this was often discussed in a way that was disconnected from policy, as though low inflation was some exogenously imposed condition the RBA was having to contend with rather than a reflection of current and past monetary policy settings. On this occasion, however, Governor Lowe noted that the RBA was responsible for nominal outcomes. He conceded that, even before the pandemic, inflation and wages had been weak for 'too many years', and this was why the RBA was now looking to tighten policy to a schedule somewhat behind some other central banks (Lowe, 2020d).

Governor Lowe noted that the economy was transitioning from recovery to expansion, but monetary policy was still well short of achieving its goals. This only served to underscore how inadequate the bank's initial pandemic response was. The policy settings that were put in place in March 2020 were supposed to address 
a downturn far more serious than the one that eventuated. Had the downturn been as severe as the RBA projected in its central case, much less its downside case, monetary policy settings would have been even more inadequate to the task.

The planned taper in bond purchases sent a strong signal the RBA wants and expects to exit QE. Had the run rate been kept at $\$ 5$ billion a week without a fixed program size or review date, the program would have been essentially open-ended and could even have been viewed as expansionary by markets. In his remarks following the July board meeting, Governor Lowe emphasised that the effect of QE was via the stock rather than the flow of bond purchases, but a reduction in the flow means a smaller expected stock, all else being equal, so that distinction does not in itself provide excuse to taper.

Lowe did emphasise that the outlook for bond purchases was symmetrical in the RBA's view and the program could be expanded in future, but the taper announcement undermined any symmetry in market expectations. The RBA was repeating the Fed's mistake following 2008 in trying to exit QE too early, which ultimately led to new QE episodes.

The RBA's commitment to hold the cash rate steady for three years was always subject to the loophole that both the yield target and QE could be abandoned ahead of any lift in the cash rate. This goes to the point long made by monetarists that the cash rate is a poor indicator of the stance of monetary policy. By the time the cash rate is raised, monetary conditions will have already been substantially tightened, not least through the expectations channel. Governor Lowe says the RBA is maintaining support until its threshold conditions for a lift in the cash rate are met, but the RBA effectively began tightening monetary policy in July 2021, not 2024, even though it remains well short of its targeted inflation and full employment goals.

\section{The RBA versus its $\mathrm{G} 10$ peers}

The RBA's policy response can be compared with that of its G10 peers based on the expansion in its balance sheet relative to GDP. While the size of a central bank's balance sheet is not a perfect measure of the stance of monetary policy, it is nonetheless a reasonable proxy, especially when outright asset purchases explicitly designed to have an expansionary effect are the largest source of change in the balance sheet. Figure 1 shows how the RBA's balance sheet expansion lagged that of its peers, particularly in the critical period from March to November 2020, when the RBA mostly relied on its traditional operating framework to ease policy. Much of the initial expansion in the RBA's balance sheet in March 2020 was driven by the bank's liquidity operations to maintain orderly functioning of the bond market rather than a program of outright bond purchases designed to ease policy. There was also limited short-duration bond buying in support of the yield curve target between March 
and May 2020. Even after the RBA adopted an aggressive bond-buying program in November 2020, it still struggled to match its peers, with convergence in balance sheet expansion with the likes of the Bank of Canada reflecting the tapering of their own programs as much as RBA balance sheet expansion.

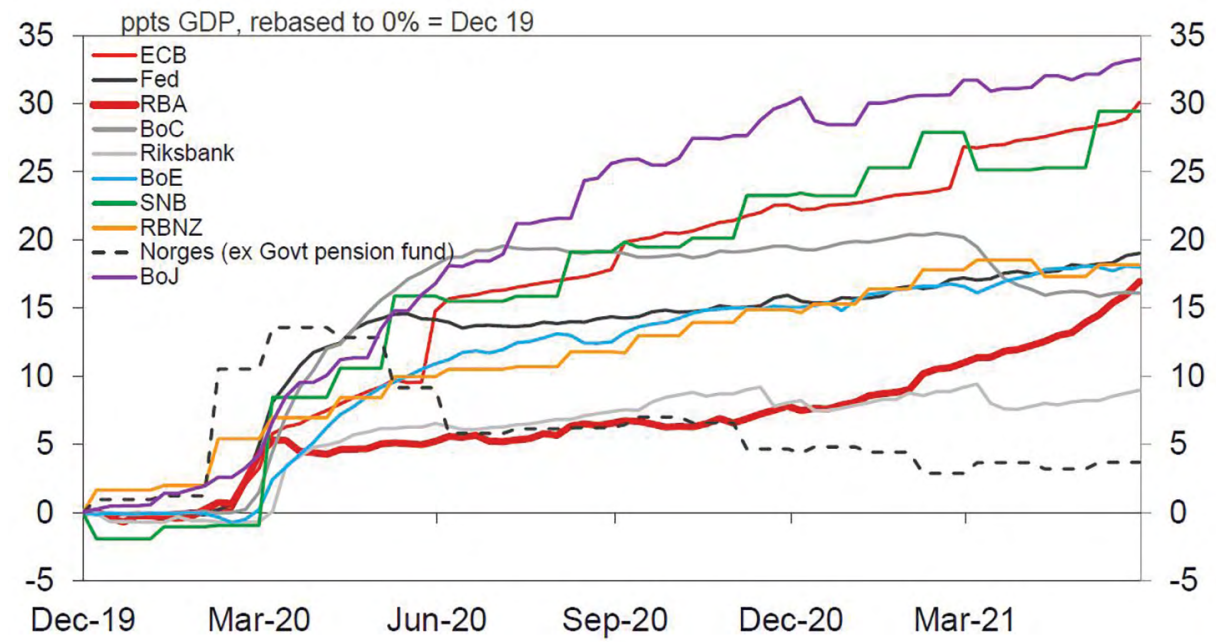

Figure 1. Change in central bank balance sheet assets (percentage of GDP) Sources: Bloomberg; McColough et al. (2021).

\section{The macroeconomic policy mix}

Australia's fiscal policy response was one of the largest among advanced economies. Table 1 shows that Australia's fiscal expansion, as measured by government spending and tax measures, was behind only the United States, New Zealand and the United Kingdom.

Table 1. Discretionary fiscal response to Covid-19: Advanced economies (percentage of GDP)

\begin{tabular}{|l|r|r|}
\hline Country & Additional spending and forgone revenue & Equity, loans, and guarantees \\
\hline Denmark & 3.5 & 15.7 \\
\hline Sweden & 4.2 & 5.3 \\
\hline Finland & 4.3 & 7.5 \\
\hline South Korea & 4.5 & 10.1 \\
\hline Norway & 7.4 & 4.5 \\
\hline Spain & 7.6 & 14.4 \\
\hline Switzerland & 7.8 & 6.2 \\
\hline Belgium & 8.2 & 11.9 \\
\hline
\end{tabular}




\begin{tabular}{|l|l|l|r|}
\hline Country & Additional spending and forgone revenue & Equity, loans, and guarantees \\
\hline France & 9.6 & 15.2 \\
\hline Czech Republic & & 9.6 & 15.5 \\
\hline The Netherlands & & 10.3 & 8.1 \\
\hline Italy & & 27.8 & 35.3 \\
\hline Germany & 13.64 & 4.0 & \\
\hline Canada & 15.9 & 16.7 & \\
\hline United Kingdom & 16.2 & 28.3 \\
\hline Japan & 16.5 & 1.8 \\
\hline Australia & 18.4 & 4.7 & \\
\hline Singapore & 18.4 & 1.6 & \\
\hline New Zealand & 19.3 & 2.4 \\
\hline United States & 25.4 & & \\
\hline
\end{tabular}

Source: IMF (2021).

There is an important difference in the exchange rate response to monetary and fiscal stimulus in small, open economies with floating exchange rates. While the exchange rate will amplify relative monetary expansion with a depreciation, it will offset relative fiscal expansion with an appreciation. The RBA's reluctance to embrace QE and its subsequent catch-up, together with a relatively large fiscal policy response, gave Australia a suboptimal macro-policy mix. To be clear, this is an argument for monetary policy to have done more, not necessarily for fiscal policy to have done less. Fiscal policy had a role to play in helping to keep the supply side of the economy intact-in particular, preserving matching capital in the labour market that would otherwise be lost in the absence of widespread wage subsidies.

In pre-pandemic remarks to The Australian National University's Crawford School, Governor Lowe showed he had little conviction in the exchange rate channel for monetary policy transmission in the context of a concerted monetary expansion by other central banks:

If everyone is easing then there is no exchange rate channel. We trade with one another, not with Mars. So if everyone is easing the effect you get from exchange rate depreciation isn't there so you don't get the stimulus you normally get from monetary easing ... It might be possible if you ease a bit more than others-you might get a bit extra growth-but that is a dangerous path to go down. (Cranston, 2021)

Lowe's remarks failed to consider the implications of a monetary expansion that was significantly smaller than that implemented by other countries. As Table 2 shows, the Australian dollar exchange rate experienced a broad-based appreciation from March 2020_-indicative of a macroeconomic policy mix that was overly reliant on fiscal relative to monetary expansion. Not all this outperformance can be attributed to the macroeconomic policy mix. The outperformance was less pronounced against 
the New Zealand dollar, with New Zealand having a similar experience to Australia in containing the pandemic, at least in 2020, but the Reserve Bank of New Zealand engaged in large-scale asset purchases much earlier and indicated a willingness to employ negative interest rates.

Table 2. Australian dollar exchange rates versus G10 peers

\begin{tabular}{|l|r|r|r|r|r|r|r|r|}
\hline \multicolumn{2}{|l|}{ AUD Exchange Rates versus G10 Peers: March 2020 $\mathbf{1}$} \\
\hline & AUDCAD & AUDUSD & AUDCHF & AUDEUR & AUDGBP & AUDJPY & AUDNZD & AUDTWI \\
\hline $2020 \mathrm{M} 03$ & 1.00 & 1.00 & 1.00 & 1.00 & 1.00 & 1.00 & 1.00 & 1.00 \\
\hline $2020 \mathrm{M} 04$ & 1.04 & 1.06 & 1.08 & 1.08 & 1.05 & 1.05 & 1.04 & 1.06 \\
\hline $2020 \mathrm{M} 05$ & 1.05 & 1.08 & 1.08 & 1.07 & 1.08 & 1.07 & 1.04 & 1.07 \\
\hline $2020 \mathrm{M} 06$ & 1.07 & 1.11 & 1.10 & 1.09 & 1.12 & 1.11 & 1.04 & 1.10 \\
\hline $2020 \mathrm{M} 07$ & 1.11 & 1.17 & 1.10 & 1.08 & 1.10 & 1.13 & 1.05 & 1.13 \\
\hline $2020 \mathrm{M} 08$ & 1.10 & 1.19 & 1.12 & 1.10 & 1.10 & 1.16 & 1.06 & 1.14 \\
\hline $2020 \mathrm{M} 09$ & 1.09 & 1.15 & 1.10 & 1.08 & 1.11 & 1.12 & 1.05 & 1.11 \\
\hline $2020 \mathrm{M} 10$ & 1.07 & 1.14 & 1.09 & 1.08 & 1.09 & 1.10 & 1.04 & 1.09 \\
\hline $2020 \mathrm{M} 11$ & 1.10 & 1.20 & 1.13 & 1.10 & 1.11 & 1.15 & 1.02 & 1.12 \\
\hline $2020 \mathrm{M} 12$ & 1.12 & 1.25 & 1.15 & 1.12 & 1.13 & 1.19 & 1.04 & 1.16 \\
\hline $2021 \mathrm{M} 01$ & 1.12 & 1.24 & 1.15 & 1.13 & 1.11 & 1.20 & 1.04 & 1.15 \\
\hline $2021 \mathrm{M} 02$ & 1.13 & 1.27 & 1.20 & 1.15 & 1.12 & 1.24 & 1.04 & 1.18 \\
\hline $2021 \mathrm{M} 03$ & 1.09 & 1.23 & 1.21 & 1.16 & 1.11 & 1.26 & 1.06 & 1.17 \\
\hline $2021 \mathrm{M} 04$ & 1.09 & 1.26 & 1.19 & 1.14 & 1.11 & 1.27 & 1.05 & 1.18 \\
\hline $2021 \mathrm{M} 05$ & 1.06 & 1.25 & 1.17 & 1.13 & 1.09 & 1.27 & 1.04 & 1.16 \\
\hline
\end{tabular}

Sources: Reserve Bank of Australia, Economic and Financial Statistics, Table F11; author's calculations.

\section{Conclusion}

The Reserve Bank left Australia poorly positioned for a major adverse shock in its pre-pandemic conduct of monetary policy, underperforming on its inflation mandate since the end of 2014. As the 'effective lower bound' for the official cash rate loomed, Governor Lowe insisted that it was 'very unlikely' the RBA would need to resort to $\mathrm{QE}$ and hinted darkly at adverse effects from the use of alternative policy instruments, although these effects were never fully elaborated and did not reference academic research based on overseas experience. The RBA viewed the implementation and transmission of monetary policy almost exclusively in terms of the cash rate as a proxy for the risk-free interest rate and only belatedly acknowledged a role for quantitative policy instruments and channels for monetary transmission. 
The RBA's initial response to the pandemic was limited, while it sought to push responsibility for macroeconomic stabilisation on to fiscal policy, but this left Australia with a suboptimal macroeconomic policy mix that put upward pressure on the exchange rate. Even after the RBA sought to correct its error in November 2020 , its aggressive program of bond purchases left it lagging behind other central banks and struggling to meet its goals even as the Australian economy resumed its expansion after the pandemic downturn. If the economy had evolved in line with the RBA's initial base case, much less its downside scenario, the policy response would have been even more inadequate.

This episode highlights the danger of being overly wedded to a New Keynesian conception of monetary policy - in particular, giving too much weight to an overnight interest rate as the main instrument and transmission mechanism for policy and assuming the effective lower bound is a constraint on monetary policy effectiveness. These mistaken beliefs inhibited the RBA's initial policy response as it sought to implement policy within its traditional operating framework, even though that framework was already yielding suboptimal macroeconomic outcomes, even before the onset of the pandemic. In Kirchner (2021), I outline how a monetarist conception of monetary policy could be embedded in a reformed governance, transparency and operating framework for Australian monetary policy. A nominal income-level target would substitute for the inflation target, while a nominal GDP futures market would help inform monetary policymaking. This approach would alleviate both the incentive and the knowledge problems inherent in the current governance and operating framework that explain why the RBA has fallen systematically short of its mandate.

The RBA's systematic underperformance against its mandate has sparked calls for a review of monetary policy (Wright, 2021). The RBA's conduct of monetary policy has not been publicly reviewed during the entire history of inflation targeting since 1993, in sharp contrast to the regular public reviews of other central banks. The Treasurer should appoint a panel of international and local experts to review the RBA's performance and make recommendations for reform.

\section{References}

Cranston, M. (2021). Depreciating \$A a 'dangerous path': RBA. Australian Financial Review, 25 June. Available from: www.afr.com/policy/economy/depreciating-a-a-dangerous-pathrba-20190625-p520yo.

Doherty, E., Jackman, B. \& Perry, E. (2018). Money in the Australian economy (BulletinSeptember). Reserve Bank of Australia. Available from: www.rba.gov.au/publications/ bulletin/2018/sep/money-in-the-australian-economy.html. 
International Monetary Fund (IMF). (2021). Fiscal Monitor Database of country fiscal measures in response to the Covid-19 pandemic. Database of Fiscal Policy Response to Covid-19. October. International Monetary Fund. Available from: www.imf.org/en/ Topics/imf-and-covid19/Fiscal-Policies-Database-in-Response-to-COVID-19.

Kirchner, S. (2018). Money too tight to mention: The Reserve Bank of Australia's financial stability mandate and low inflation. Economic Analysis and Policy, 60 (December), 141-49. doi.org/10.1016/j.eap.2018.09.014.

Kirchner, S. (2021). Reforming Australian monetary policy: How nominal income targeting can help get the Reserve Bank back on track (Monetary Policy Working Papers, 27 January). Mercatus Centre, George Mason University. Available from: www.mercatus.org/ publications/monetary-policy/reforming-australian-monetary-policy-how-nominalincome-targeting-can.

Lowe, P. (2019). Unconventional monetary policy: Some lessons from overseas. Address to Australian Business Economists Dinner, Sydney, 26 November. Available from: www. rba.gov.au/speeches/2019/sp-gov-2019-11-26.html.

Lowe, P. (2020a). Reserve Bank of Australia annual report 2019 (Official Committee Hansard, 7 February). House of Representatives Standing Committee on Economics. Available from: parlinfo.aph.gov.au/parlInfo/search/display/display.w3p;query=Id\%3A\%22committees \%2Fcommrep\%2Fcd2f4ebe-8e89-48fc-9d73-511ad37ff580\%2F0001\%22.

Lowe, P. (2020b). Statement by Philip Lowe, Governor: Monetary policy decision (Media release, 19 March). Reserve Bank of Australia. Available from: www.rba.gov.au/mediareleases $/ 2020 / \mathrm{mr}-20-08$.html.

Lowe, P. (2020c). The recovery from a very uneven recession. Speech to Citi's 12th Annual Australia and New Zealand Investment Conference, Sydney, 15 October. Available from: www.rba.gov.au/speeches/2020/sp-gov-2020-10-15.html.

Lowe, P. (2020d). Today's monetary policy decision. Speech, Sydney, 3 November. Available from: www.rba.gov.au/speeches/2020/sp-gov-2020-11-03.html.

McColough, D., Ren, J., Franulovich, R. \& Rennie, R. (2021). Macro bites update. 27 October. Westpac Institutional Bank. Available from: westpaciq.westpac.com.au/.

Wright, S. (2021). The central bank under fire: Has the RBA failed Australians? Sydney Morning Herald, 5 April. Available from: www.smh.com.au/politics/federal/the-centralbank-under-fire-has-the-rba-failed-australians-20210315-p57auu.html. 
This text is taken from Agenda, Volume 28 - Number 1, 2021 edited by William Coleman, published 2021 by ANU Press, The Australian National University, Canberra, Australia.

doi.org/10.22459/AG.28.01.2021.06 